\title{
RISK FACTORS OF LATENT TUBERCULOSIS AMONG HEMODIALYSIS PATIENTS
}

\author{
Yusup Subagio Sutanto, Astuti Setyawati \\ Department of Medical Pulmonology and Respiratory, Faculty of Medicine, Universitas \\ Sebelas Maret/ Dr. Moewardi Surakarta Hospital
}

\begin{abstract}
Background: Tuberculosis (TB) remains one of the most important infectious diseases worldwide. Latent TB occurs when a person has the TB bacteria within their body, but the bacteria are present in very small numbers.Tuberculosis in end-stage renal disease patients on regular hemodialysis (HDPs) presents a number of diagnostic challenges.This study aimed to investigate the risk factors of latent tuberculosis among hemodialysis patients.

Subjects and Method: This was a cross sectional study carried out at Dr. Moewardi Hospital, Surakarta, Central Java, in May 2018. A total of 30 patients was selected for this study. Latent tuberculosis was measured by recorded baseline data, tuberculin skin test (TST), and T-SPOT.

Results: $23.3 \%$ patients were latent tuberculosis, $20 \%$ had positive TST, and $16.7 \%$ had T-SPOT.TB positive. Hemodialysis was significantly associated with positive TST results $(\mathrm{OR}=0.04 ; 95 \% \mathrm{CI}=0.01$ to $0.89 ; \mathrm{p}=0.042)$. Gender, age, body mass index (BMI), comorbidities, TB contacts, Bacille Calmette Guerin (BCG), duration of hemodialysis, and the number of T lymphocyte cells cluster of differentiation 4+ (CD4+) were not significantly associated with latent tuberculosis.
\end{abstract}

Conclusion: Hemodialysis is significantly associated with positive TST results.

Keywords: risk factors, latent tuberculosis, TST, T-SPOT. TB, hemodialysis

\section{Correspondence:}

Yusup Subagio. Department of Medical Pulmonology and Respiratory, Faculty of Medicine, Universitas Sebelas Maret/ Dr. Moewardi Surakarta Hospital, Central Java. Email: dr_yusupsubagio@yahoo.com. Mobile: 0811284165.

The $5^{\text {th }}$ International Conference on Public Health Best Western Premier Hotel, Solo, Indonesia, February13-14, 2019 | 689 https://doi.org/10.26911/theicph.2019.05.35 